\title{
Domestic water conservation practices in Tlemcen City (Algeria)
}

\author{
Mohammed Habi · Omar Harrouz
}

Received: 6 December 2013/ Accepted: 4 March 2014/Published online: 19 March 2014

(C) The Author(s) 2014. This article is published with open access at Springerlink.com

\begin{abstract}
During the last three decades, citizens of an Algerian city are concerned with the problem of drinking water supply. Time discontinuation service became the rule. The central idea of the analysis based on interviews is to assess the role of water in the organization of the relationship between habitat and users. The fundamental question is how users, in particular women, incorporate water in their daily lives due to rationing. Having to deal with the discontinuous and frequent weak water supply, the inhabitants of the city of Tlemcen who are connected to the water supply system, as well as those connected to the water system of all Algerian towns, have developed an internal water storage system to sort out this problem. The imposed rationing has proved to be expensive for consumers. The water shortage pushed the consumers to invest in relatively expensive storage and pumping facilities to satisfy their domestic needs. As the frequency of the water supply is on a two times per week basis, the survey reveals a discrepancy in terms of volumes consumed and stored by each household. The use of water depends on the individual storage facility and the frequency of the supply. The life of the households, particularly that of the housewives, depends on the availability of water and thus on the schedules of the Company of Production of Water
\end{abstract}

M. Habi ( $\square)$

Professeur, Département d'Hydraulique, Faculté de Technologie, Université de Tlemcen, B.P. 230, 13000 Tlemcen, Algeria

e-mail: moha.habi@gmx.de

\section{O. Harrouz}

Docteur enseignant à l'Institut des Sciences de la Nature et de l'Agro-alimentaire de Bordeaux, 2, Impasse Charles-Tellier, Villenave-d'Ornon Cedex, 33883 Bordeaux, France
"Algerian Des Eaux" (ADE). This is particularly the case when they are supplied during the night.

Keywords City of Tlemcen - Water - Rationing · Frequency $\cdot$ Storage system $\cdot$ Supply time

\section{Introduction}

The alarming shortage of freshwater faced by certain countries requires urgent and immediate action, in particular, those in the arid and semi-arid areas of the globe, which do not have sufficient water and land resources to ensure the survival of the increasing population. In this regard, Algeria is among the most vulnerable areas of the world, based on the threshold of water scarcity fixed at $1000 \mathrm{~m}^{3} /$ inhab./year (Kettab 2001; CNES 2000). Algeria belongs to countries with low hydraulic resources. During the last 25 years, the country went through a long period of severe and persistent drought, characterized by an important rainfall deficit, estimated at about $30 \%$ for the whole country. During 2001-2002, this shortfall reached $50 \%$ (ANRH 2004).

Due to the low levels of precipitation, the west of Algeria will be most affected by water shortage. The drought which has prevailed for more than two decades has desiccated the subsoil, causing serious disruption of the 1,000-year-old water-bearing layer. The study focuses on an area located in the Tlemcen Province at the extreme northwest of Algeria. The Urban Grouping of Tlemcen (UGT) has developed in the center of the province on the northern piedmont of the Mounts of Tlemcen. It includes the city of Tlemcen and some of its suburbs, which jointly form the town of Tlemcen. In 
addition to the great urban centers which account for more than 200,000 inhabitants, the territory also includes the Meffrouche dam, which is used as a source of drinking water supply. The dam is established along the Wadi Enechef (or Meffrouche), a few kilometers away in the southeast on a karstic plateau overlooking the city.

Over the last 25 years, there has been a significant decline in rainfall. Consequently, the quantities of water flowing into the catchment's basins of the dam have decreased and the basins are filled only partially. The Meffrouche dam, designed to provide $14 \mathrm{hm}^{3} /$ year, has only delivered $4 \mathrm{hm}^{3} /$ year of drinking water on average during the recent years (ADE 2007).

The production of groundwater increased dramatically over the last 20 years, to make up for the shortfall of surface water supply and also to meet a rise in demand, particularly in the Urban Grouping of Tlemcen.

Such a growth of production does not come about without repercussion on the capacity of the water-bearing layer. The output of the sources has sharply decreased since their start-up and the level of groundwater has dropped, often in a rather drastic way.

To overcome the low supply of drinking water, the water services drilled and operated a large number of wells. This is in addition to the huge number of wells drilled throughout the town of Tlemcen (more than 720 wells for domestic use, without any permanent and proper control) (ANRH 2004).

To combat the deficit and with the hope of limiting the household consumption, Algeria has applied a program of water rationing since 1985. In this context of shortage of resources and inappropriate management, the strategies developed by various social groups can bring new practices to overcome certain incapacities. The modes of organization established in various districts of the city of Tlemcen are examples of short-term options.

The users adopt strategies to overcome the service deficiencies. These strategies are partially conditioned by the socioeconomic characteristics of the households. The storage of water is the most spread solution (the purchase of reservoirs, jerry cans and the construction of tanks). The second important strategy is the organization of the activities according to the Company of Production of Water "Algerian Des Eaux" (ADE) schedules of distribution, besides the purchase of water from private water sellers.

For many, holidays are far from being their main concern, since the priority of water availability is acutely felt. Roving water merchants and tankers of the ADE crisscross every corner of the districts to supply families with this valuable liquid. The inhabitants try to be patient and adapt to the situation. In a number of districts of the city, one sees groups of three or four, each carrying a jerry can or an empty can, begging for water. "It is hot and we need water for drinking, for household chores and to wash. And when we are deprived of water for 3 days, the situation becomes unbearable. We spend the whole day looking for water. When it is available in the taps, we fill everything from jerry cans to every barrel, and all possible containers and try to save it to the maximum; it "evaporates" very quickly. One can do nothing, it is summer", deplores a mother of a family. "During the days when water is available in the taps, we try to do the utmost: such as the laundry which has accumulated for several days, baths for children and for us as well as other domestic tasks. But, hardly do we start the water from the tap runs out". "It is an exhausting and irritating situation", says another.

Since the schedule of supply is not respected by the "ADE', and it is done mainly by night, families get organized, in turn, waiting for the valuable liquid. Even if the schedule of supply is respected, the shortage has affected the water pressure. As a result, water does not go up beyond the first or the second floor of a building and rarely the third. Water does not reach the inhabitants of the higher floors, with or without the rationing schedule.

Connecting a pump to the main water pipe of a building and pumping water to higher floors has become a very current practice in the city of Tlemcen. The crisis of water and the frequent lack of pressure seem to support this practice, which is illegal and environmentally harmful to the neighbors living in the same building. Many consumers are unhappy these days and everyone wonders how this directly consumed water from the main pipe is paid.

According to the "ADE', this practice is not authorized and is illegal. But the company is unable to enforce the law against consumers who use pumps. The inhabitants of higher floors of buildings attribute this practice to the lack of pressure preventing water from reaching the higher floors.

For a long time having been victims of misleading illusions and promises from the authorities, the citizens have become increasingly impatient and agitated about the crisis of water. This situation persists in spite of various projects, which were initiated more than two decades to reduce the shortage but remain either incomplete or have missed their completion.

On one hand, a minority among the population show resignation and docility with respect to these "fables" and passively continue receiving water once every 
14 days and buying water from roving tank owners to satisfy their needs. On the other hand, however, the majority of people are dissatisfied because they do not understand the reasons for the long delays in the execution, implementation and completion of the projects. In addition to the time it takes and the financial cost, the citizens living in multi-story buildings, ask the roving tank owners to undertake extra effort and dangerous work by climbing on the roof and dragging heavy water pipes to fill the fixed tanks on the roof. This valuable resource is costing them more than 35 cents per liter, which is excessively expensive for modest incomes (the wealthiest people are miles away from this crisis because their houses are equipped with several tanks and large built-in reservoirs).

\section{Methodology of collection and analysis of data}

To investigate the problem, we established a survey to collect socioeconomic and hydraulic data, and the relation between individuals, particularly women and their environment, according to the hydraulic problems that they encounter.

The central idea of the analysis, from our interviews, is to appreciate the place of water in the organization and the relation between the individuals and their environment. The fundamental question was to know how the individual, and in particular women, integrate water into their daily task.

The data collection was realized in greater Tlemcen area, which includes the municipalities of Tlemcen, Mansourah and Chetouane.

The questionnaire prepared for the purpose of data collection contains four sections:

(a) General aspects: gender of the participants, housing tenure the total number of people living in the housing and housing type (individual or collective).

(b) Knowledge regarding the source of the water consumed in Tlemcen and the opinion on the causes of the irregular service:

(c) The water supply is divided into two aspects:

(c.1) connection, existence of meter or subscription package, functioning or breakdown of the meter;

(c.2) knowledge, the estimated daily consumption and the sale price of $\mathrm{m}^{3}$.

(d) The distribution of the water is divided two aspects:

(d.1) frequency of distribution and number of hours of running water; (d.2) satisfaction regarding the quantity of water received, the use of alternate sources, water conservation methods and its re-use.

After the elaboration of our inquiry, the choice of the representativeness of the sample arose. A random approach was established in these three municipalities, while taking into account the urban specificities which are the dominance of a type of living: traditional house and villas in the city of Tlemcen, apartments and single-family dwellings in Mansourah and Chetouane.

In in this kind of research, the methods used are diverse as well as quantitative and qualitative; the adopted approach is field inquiry. We chose to hire students for the collection of data rather than to follow the suggestion of using employees from the statistics department to avoid giving the survey an official nature and avoid confusions concerning the questions on the standard of living.

The team of investigators was composed of 25 students over a 1-month period and we divided them into 20 investigators, 4 supervisors and 1 assistant in computing for the introduction of data.

Once the questionnaire was approved by the various people in charge, we proceeded with training the investigators for 1 day and used another day to test them in a neighbouring village of Tlemcen, not included in the survey.

Every supervisor was responsible for a team of five investigators; each questionnaire was codified before its application to avoid duplications.

The survey was conducted by sectors, all teams worked at the same time and each of them was responsible for a unit of survey distributed by us.

Many interviews were conducted with different individuals involved in the functioning of the urban services (users, people in charge of the service of water and the informal sector of water resale).

The total number of inquiries realized in the three municipalities is 2,579, which represents $\sim 9 \%$ of our estimation of 210,000 inhabitants (about 29,750 families), residing in seven sectors (popular districts, middle class and upper class). We consider that these society class levels differ in their management of water and do not have the same relationship with the water management administration. The inquiries were performed according to the standard of living and the size of the household.

The objective of the study is to analyze the behavior of the citizens with regard to water rationing; an exploratory inquiry was carried out in the Urban Grouping of Tlemcen. 


\section{Results of the investigation}

\section{Communication problems}

In our opinion, there is a lack of communication between the consumers and the "ADE". Moreover, awareness programs as to the water issue are virtually non-existent: otherwise, how can one explain that only $40 \%$ of the surveyed people stated that they knew the origin of the water they consumed! In addition, $62.8 \%$ do not know their consumption and $92.3 \%$ are unaware of the price they are paying for 1 cubic meter of water.

On the other hand, $40 \%$ of the studied households misunderstood the reasons for the irregularity in the distribution of water; this situation is understandable considering the lack of information emanating from the services in charge of water supply. The patterns rose by certain households are the incapacity of production or the continuous works on the network. It is necessary to say that these reasons are the ones often advanced by the services in charge of water supply to justify the prolonged cuts to the population, without questioning its unequal management of the supply.

Generally, the inhabitants of the Urban Grouping of Tlemcen (UGT) are satisfied by the quality of the distributed water $(92 \%)$, and only about $8 \%$ find that the quality is bad (cloudy water, bad taste). This is a high percentage when compared with surveys conducted in other countries such as that reported in Amman Jordan where only $5 \%$ of inquiries assert that the water of the network is of a good quality, while $65 \%$ find that the quality of the tap water is inferior (Darmame 2003).

Rationing methodology

One of the most unacceptable facts and common complaints is the lack of prior notification to the consumers when water supply is disrupted in a given sector of the city.

At this time, rationing seems to be the only way of managing water shortage in Tlemcen. The rationed households seem to have adapted and developed strategies of storage, which depend on the frequency of water supply.

The schedule of drinking water supply, concocted by the ADE and applied for several years to Tlemcen, was anticipated to serve on average twice a week one district of the city and once a week the other districts. No one knows why such a difference exists. Also, it was found that only $2 \%$ of the surveyed families were

$\begin{array}{lr}\text { more than twice a week } 10 \% & 10 \% \\ \text { everyday } 2 \% & 2 \% \\ \text { once a week } 13 \% & 13 \% \\ \text { twice a week } 75 \% & 75 \%\end{array}$

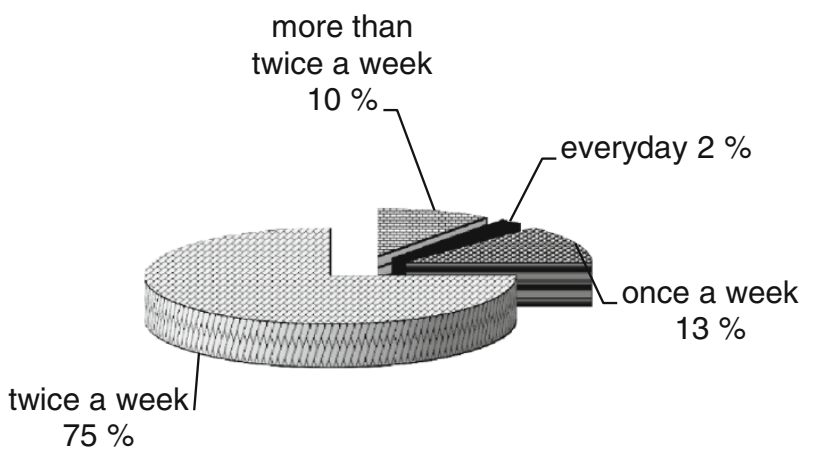

Fig. 1 Water supply frequency

supplied every day (Fig. 1). The ADE representative was surprised to learn that some people were supplied continuously. According to the ADE representative, these households are supplied by illegal connections from the main water pipe. These hackings are one of the consequences of the increase in the drinking water consumption not accounted for by the ADE. These quantities are not billed. These households are supplied all day and are therefore in a privileged situation compared to the legally connected users who endure the restrictive rationing.

The rationing combined with the randomization of the hours of supply creates strong tensions within the population. Indeed, the life of the households, particularly that of housewives, depends on the availability of water and thus on the schedules of the ADE. This is particularly the case when they are supplied during the night.

Theoretically, the ADE ensures 6-7 h of water supply on average per day. However, these time rates remain very theoretical because they do not take into account many factors such as opening of the valves and the state of the supply system. The majority of the women surveyed complained about the variation of the hours of distribution and were mainly supplied during night with extensions into the morning. Only $5 \%$ of the households were supplied during the day and this from 2 am up to $11 \mathrm{pm}$, but still on an irregular basis (Fig. 2).

Developed to fight against the deficit, to limit the household consumption and to establish a fair distribution, the rationing became widespread in all the Algerian cities.

Although there is a general lack of water in all the sectors of the city of Algiers, the various districts of the 


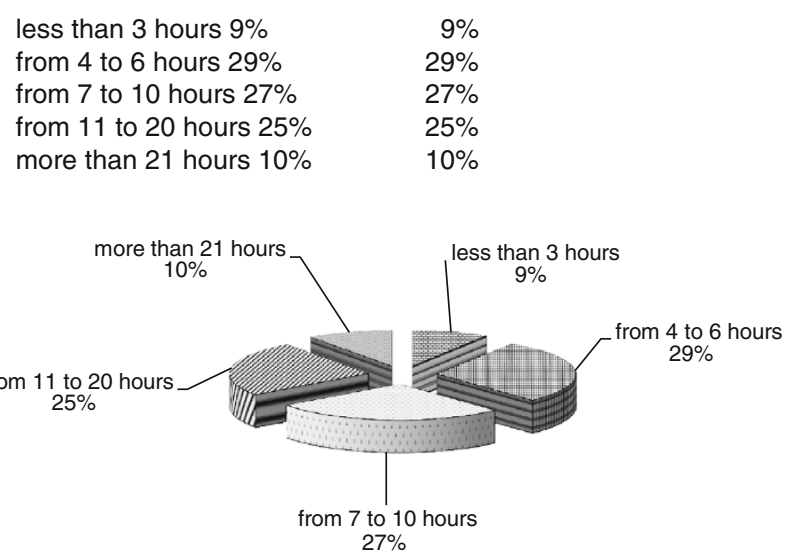

Fig. 2 Water supply time

capital are not subjected in the same way to the management of the shortage. Indeed, the rationing, almost nonexistent in Hydra (well doing populations), is present in Kasbah and Belfort (underprivileged populations). In theory, the distribution is assured for $6-10 \mathrm{~h}$ a day. Certain districts were supplied $1 \mathrm{~h}$ only (Chikhr 2001).

In Oran (the second biggest Algerian city) the rationing of water is the rule in the major part of the city (Senouci 1995; Senouci 1997a, b). The organization of the distribution in the daytime varies according to the districts. Water is available in the network every 3 or 4 days according to the zone of distribution and its time span is $6-12$ h only (Fouatih et al. 2007).

The situations are practically similar in all other African cities (Abidjan, Nouakchott, Dakar or Bamako...). For example in Djibouti, the districts of the city where well doing population live benefit from an almost continuous supply. Next to this part of the city exists another sector which corresponds to the popular districts; the supply of this sector is intermittent with schedules of random distributions without a pre-established program. Certain districts, more close to the residential sector, receive water a little longer (6-7 h a day), while others, outlying or situated at a height are supplied only $2-3 \mathrm{~h}$ during the night (Rayeleh 1995, 2004).

Finally, Jordan is one of the ten countries that is most threatened by water shortage in the world; it applies a program of rationing of water since 1988 with the objective of reducing the technical losses, estimated to be $35 \%$ of the produced water and to dissuade the big consumers. The districts situated near the royal palaces or the big reservoirs are served two to three times a week. In other districts of Amman the water arrives once a week. The hours of distribution vary from 24 to $48 \mathrm{~h}$. During the summer season, the households receive water only one or two times a week, for durations from 12 to $24 \mathrm{~h}$ (Darmame 2003, 2004).
Storage mode

To remedy the shortage of water, storage becomes widespread. The user elaborates inside his house his own strategies.

Storage brings to light the discriminating roles of income and the irregularity of the supply. So households with high incomes often choose expensive strategies (reservoirs of big sizes generally placed on the roof, tanks buried under or next to the house-building, electric engines); indeed, $58.3 \%$ of the Tlemcenees households use reservoirs of a capacity of $1-3 \mathrm{~m}^{3}$ and $5.4 \%$ possess tanks of capacity of more than $4 \mathrm{~m}^{3}$ against, respectively, 70 and $10 \%$ of the households in Amman (Darmame 2003).

On the other hand, the underprivileged households will compensate for the deficiencies by the time dedicated to the reorganization of their activities and to the storage in more reduced reservoirs. In Tlemcen $36.3 \%$ use basins, barrels and even plastic bottles, like everybody else in Algiers, with the exception of Hydra because of a continuous supply. Of the 93 women asked, 54 store water in jerry cans, basins and container (Chikhr 1997).

The situations are similar in Oran, Abidjan, Nouakchott, Dakar, N'djamena, Libreville and in Djibouti; households use more tins, casks of water recovery, jerry cans and big plastic buckets because of their resistance to corrosion (D'hont 1988).

In Tlemcen, as the frequency of water supply is two times per week basis, the survey reveals a discrepancy in terms of volumes consumed and stored by each household. The use of water depends on the individual storage facility and the frequency of the supply. The volume stored by household 1 which uses a traditional storage mode, and household 2 which uses sophisticated means (water tank and pumping station) in addition to the traditional storage mode, is respectively 600 and 2,400 L every time water is available from the tap. This represents a water consumption of $30 \mathrm{~L}$ per day per inhabitant for household 1 and $117 \mathrm{~L}$ per day per inhabitant for household 2 .

The use of reservoirs and covers allows storing of an important volume of water between two frequencies of distribution. However, this system consisting of reservoir, piping, overpressure and the realization of the works is excessively expensive $(\sim 20000 \mathrm{AD}, 1$ Euro $=98 \mathrm{AD})$ for a modest purse. For a reservoir of $1 \mathrm{~m}^{3}$ of an inferior quality, a Jordanian pays 50/60 JD ( $1 \mathrm{JD}=1.43 \mathrm{USD}$ ) (Darmame 2003).

Confronted with the irregularities of supply and the repetitive cuts of water, the households tend to store much more water than what they really need.

The storage of water thus led to the development of wasting behavior, a paradoxical practice in the context of shortage. It would be wiser to establish a clear program of rationing with time slots well defined by sectors, to decrease the overconsumption. 
The water is stored all week in reservoirs often in the terrace roof, exposed to the sun and impurities, which could create an underestimated health risk. The public awareness toward the risks of degradation of the water in reservoirs is practically non-existent.

\section{Impact of water shortages}

For additional needs of water or in case of irregular frequency of supply, consumers call upon informal water suppliers. This informal market of water developed in the last few years in the city of Tlemcen and in almost all the Algerian cities because of the persistency of the shortage and the inability of the water services to adequately satisfy consumers. These water salesmen use agricultural vehicles to move mobile tanks with a capacity of $\sim 3 \mathrm{~m}^{3}$. In a climate of uncertainties and anarchy, speculators benefit from this situation and sometimes sell water of low quality (coming directly from private wells), up to 20 times the price set by the authorities. The price of $3 \mathrm{~m}^{3}$ of water varies between 500 and $800 \mathrm{AD}$, and is dependent on the season and on the quality of water in the wells.

The informal sector of water occupies an important place in the supply of water to the population in the majority of developing countries. For example, in Amman it is estimated that about $30 \%$ of the households are supplied with supplementary water in the summer and pay the private salesmen at least the official price of $2 \mathrm{JD} / \mathrm{m}^{3}$ or near ten times the price of the water supplied by the WAJ (Water Authority of Jordan) (the average price was $0.206 \mathrm{JD} / \mathrm{m}^{3}$ in 1993-1999) (Darmame 2003).

In Oran the situation is even more critical because of the poor quality of water and the degree of salt it contains. The residents in several districts purchase freshwater (at a price of one dinar for $2 \mathrm{~L}$ ), which represents more than $600 \mathrm{AD} /$ month and is about 1/10th of the guaranteed minimum wage (GMW) for a family of six persons, without forgetting the expenses they have to settle with the Company of Production of Water (ADE) in the city of Oran (Tounsi 1998).

As a consequence to the difficult access to the network, the resale of water connection is officially a forbidden activity by the water services. It remains however very wide-spread in the city of Djibouti. However, resale in Djibouti is not made as in the other African cities (Abidjan, Nouakchott, Dakar or Bamako) with basins or tins (Rayeleh 2004). Households which buy water always have a garden hose at their disposal which serves to forward the water up to their place of residence, distant by several hundreds of meters sometimes.

The inhabitants of Kariat-Oulad-Moussa (Morocco) call upon the salesmen of water, especially on days of big washing and spring cleaning; at the rate of $5 \mathrm{Dh}$ the $200 \mathrm{~L}$ barrel, the expenses amount on average to $30 \mathrm{Dh}$ a month (Jolie 1991).

Tanks of all kinds installed on the roof of houses and buildings have become a singular element of the urban landscape of Algerian cities. This is true even in the most residential districts. The installation of these tanks on the roof of single-family houses does not represent a big problem. However, it constitutes a serious safety problem for buildings. Indeed, a roof can be subjected to standardized loads only $\left(100 \mathrm{~kg} / \mathrm{m}^{2}\right.$ for an inaccessible roof and $150 \mathrm{~kg} / \mathrm{m}^{2}$ for an accessible roof, taking into account extreme snowfall and maintenance work). But the presence of these tanks and the additional mass that they represent are not taken into account during the drafting of the plans and the construction of the buildings. These water reserves thus constitute a serious threat to the construction's stability and safety.

\section{Conclusions}

The frequency of water supply in the Algerian cities leads to different behaviors among the consumers. Facing the constraints of water rationing, the Algerian households adapt themselves using internal storage systems. The use of water depends on the storage capacity and the improvement of the hydraulic equipment installed to ensure adequate internal distribution within the house. The households are ready to invest more to improve their storage systems and internal distribution, to ensure a minimum of comfort. Consumers even call upon the informal water suppliers to satisfy their requirements in spite of the exorbitant costs. The solution to improve the system of distribution would be to develop a mathematical model, taking into account the phenomenon of discontinuity, with the aim of optimizing the supply of water to all consumers. Such an optimized management would allow consumers to be reassured, result in less waste of water and ultimately lead to a change in behavior. To help ensure better control of drinking water storage, its continuous distribution and availability, the education of the Algerian individual about the scarcity of water must become a priority. The only way is to allow the society to evolve and to progress toward modernity.

At this moment, everything takes place as if a certain compromise had been established between the water services and the consumers. The first one imposes rationing on districts to manage water shortage. The second practices the preservation of water to overcome the discontinuity of the supply. This process allows overcoming temporarily the deficit of production of water in the city, but gets exhausted because of the growth of needs.

The difficulties in drinking water supply which characterize developing countries call out the political authorities to provide gigantic efforts in infrastructure realizations, 
equipments and especially mobilization, protection and management of hydraulic resources.

The state should not only grant more autonomy to the bodies in charge of management and to the local authorities, but should also start procedures and reforms directed to share the responsibility of the management with the other contributors.

Partnerships between the public and private organizations can bring solutions to the problems of management of drinking water. However, they do not have to forget to take into account the social and cultural realities of the population as well as the sociopolitical context of the country.

From our results, it would be useful to develop certain aspects of our study. The question of perception of the lack of water by the consumers would be interesting to undertake. It would allow us to a certain extent understand the paradox of the unawareness behavior of certain users in the context of water shortage.
It will be desirable if work is undertaken on a smaller scale to study the capacity of the population to accept, in the near future, that water is not any more a gift of God but a consumer good, the production and preparation of which are becoming more expensive. This can facilitate the adoption and application of reforms.

Open Access This article is distributed under the terms of the Creative Commons Attribution License which permits any use, distribution, and reproduction in any medium, provided the original author(s) and the source are credited.

\section{Appendix}

AD Algerian dinar

JD Jordanian dinar

Dh Moroccan dirham

\section{Questionnaire}

The Questionnaire model utilized to assess residential water consumption practices in Tlemcen City.

\section{A. General aspects}

1. Respondent gender:

\section{Male \\ $\square$ Female}

2. What kind of house is it?

\section{Do you own / lease your house?}

$$
\text { Apartment } \quad \square \text { Single house }
$$

4. How many residents occupy your home?
$\square 1$
$\square 2$
$\square 3$

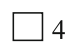
$\square 5$
$\square 6$
More than 6

5. How many bathrooms do you have?
$\square 1$
2
More than 2

6. How many kitchens do you have?
$\square 1 \quad \square 2$
More than 2

7. How many residents occupy your home?

$\square 1 \quad \square 2 \quad \square 3 \quad \square 4 \quad \square 5 \quad \square 6 \quad \square$ More than 6




\section{B. Water supply}

1. What are the main sources of water in Tlemcen?

$\square$ Surface water $\square$ Ground Water $\quad \square$ I don't know

$\square$ Other, please specify:......

2. Are you connected to the municipality water supply network?

$\square$ Yes $\quad \square$ No

3. How regular is the water supply?

$\square$ Daily $\quad \square$ 2 Days $\quad \square$ 3 Days $\quad \square$ Weekly

$\square$ Other, please specify:

4. Do you know the reason of the irregularity in the distribution of water?

$\square$ Yes $\quad \square$ No

5. Do you have a water meter installed at your house?

$\square$ Yes $\square$ No

6. If yes,

$\square$ Water meter operates $\quad \square$ Water meter does not operates $\quad \square$ not equipped with water meter

7. Do you know what your water consumption per day? $\left(\mathrm{m}^{3}\right)$

$\square$ Yes $\quad \square$ No $\quad \square$ If yes indicate a number:.

8. Is Do you know the price of drinking water?

$\square$ Yes $\quad \square$ No $\quad \square$ If yes indicate an amount:

9. Are you satisfied with the quality of the water supplied?

$\square$ Yes $\quad \square$ No

10. Is the water supply sufficient to satisfy your needs?

$\square$ Yes $\square$ No

11. Do you have water tankers installed at your home?

$\square$ Yes $\quad \square$ No

12. If yes, what is the tanker's volume? $\left(\mathrm{m}^{3}\right)$

$\square 1 \quad \square 2 \quad \square 3 \quad \square 4 \quad \square 5$

$\square$ Other, please specify: 


\section{References}

Agence Nationale des Ressources Hydrauliques (2004) Plan National de l'eau. ANRH, Alger

Algérienne des Eaux (2007) Rapport technique annuel

Chikhr SF (1997) La crise de l'eau à Alger. Une gestion conflictuelle. L'Harmattan Press. Paris, p 255

Chikhr SF (2001) Des inégalités dans l'accès à l'eau. Revue tiers monde T. XLII 166:305-315

Conseil National Economique et Social (2000) L'eau en Algérie : le grand défi de demain. Rapport du conseil national économique et social

D'hont O (1988) L'approvisionnement en eau de Nouakchott et de sa population. In Les cahiers d'Urbama 1:7-23

Darmame K (2003) Gestion de la rareté: le service d'eau potable à Amman entre la gestion publique et privée. IWMI IFPO MREA

Darmame K (2004) Les enjeux du secteur privé dans la gestion de l'eau potable. In Les Cahiers de l'Orient 75:155-169

Fouatih ZA, Benzine FZ, Mokhtari L (2007) La restriction en eau potable dans une grande ville d'Algérie: Oran. Journées Scientifiques-Gestion intégrée des eaux et des sols: Ressources, aménagements et risques en milieux ruraux et urbain, 6 au 9 novembre, Hanoi, Vietnam. Comptes rendus
Jolie M (1991) L'eau et les rapports services usagers à partir d'une politique récente de branchements généralisé: Le cas de Kariat Ouled Moussa à Rabat-Salé et les branchements sociaux. In L'eau et la ville FASC no 22 URBAMA TOURS

Kettab A (2001) Les ressources en eau en Algérie: stratégies, enjeux et vision. Desalination 136:25-33

Rayeleh HO (1995) L'accès à l'eau et les inégalités sociales dans la ville de Djibouti. Mémoire de maitrise de géographie, University of Saint-Etienne

Rayeleh HO (2004) La gestion d'une pénurie: l'eau à Djibouti. Dissertation, University of Orléans

Senouci L (1995) Le consommateur : un tiers oublié de la gestion étatique de l'eau. Montréal : Villes et Développement. Groupe interuniversitaire de Montréal, (Cahier série conférence 09-95)

Senouci L (1997) Le consommateur : un tiers oublié dans la gestion étatique de l'eau. Economica, dans Services urbains dans les pays en développement, Paris, pp 155-185

Senouci L (1997) La gestion de l'eau en situation de pénurie dans les pays en développement : une approche viable (un cas développé : Oran). Dissertation, University of Montréal

Tounsi RY (1998) Les acteurs de la gestion de l'eau dans les villes arabes. Congres international sur l'eau, 18 au 20 juin, Kaslik, Liban, Compte rendu 